\title{
PERANCANGAN ALAT UKUR INTENSITAS CAHAYA BERBASIS ARDUINO LEONARDO MENGGUNAKAN SENSOR LDR (Light Dependent Resistor)
}

\author{
Simson Manik, Abdul Muis Muslimin ${ }^{2 *}$, Aries A. Subgan ${ }^{3}$ \\ ${ }^{1,2,3}$ Prodi Fisika Jurusan Fisika FMIPA UNIPA \\ Jl. Gunung salju Amban, Manokwari - Kode Pos: 98214 \\ e-mail korespondensi: a.muslimin@unipa.ac.id
}

\begin{abstract}
Lux meter is a device used to measure the intensity of light in an area. The purpose of this thesis is to design a light intensity measuring device using LDR components as a light sensor, comparing light intensity measuring devices made using LDR sensors and Arduino Leonardo based microcontrollers with standard tools. The data used in this study are primary data. The data obtained is then processed using MS. Excel. The type of light bulbs used are Philips CFL (Philips Essential) lamps, each lamp having a power of 5, 8, 11, 14, 18, 23, 27, 32, 35, and 50 watts with a luxmeter vertical distance of 1,2 and 3 meters from the lamp.

From the results of testing the tools and processing of comparative data between the Lux Meter Standard and the designed Lux Meter obtained as follows: the vertical distance of the tool by 1 meter from the lamp produces an average error difference of 12,571 lx and the percentage of average errors the average is $8.77 \%$, while for the vertical distance of the tool is 2 meters from the lamp the average error difference value is $2,358 \mathrm{~lx}$ and the average error percentage is $7.98 \%$, and for the vertical tool distance is 3 meters from the lamp the difference in error value is an average of $0.92 \mathrm{~lx}$ and an average error percentage of $5.85 \%$.
\end{abstract}

Keywords: Arduino Leonardo, LCD, LDR, Light.

\begin{abstract}
ABSTRAK
Lux meter merupakan alat yang dipakai untuk mengukur besar intensitas cahaya di suatu lokasi. Tujuan dari penulisan skripsi ini adalah merancang alat ukur intensitas cahaya dengan menggunakan komponen LDR sebagai sensor cahaya, membandingkan alat ukur intensitas cahaya yang dibuat menggunakan sensor LDR dan mikrokontroler berbasis Arduino Leonardo dengan alat yang sudah baku. Data yang digunakan dalam penelitian ini yaitu data primer. Data yang diperoleh kemudian diolah menggunakan MS. Excel. Jenis lampu yang digunakan adalah lampu philips CFL (Philips Essential) yang masing-masing lampu memiliki daya 5, 8, 11, 14, 18, 23, 27, 32, 35, dan 50 watt dengan jarak vertikal alat sebesar 1, 2 dan 3 meter dari lampu.

Dari hasil pengujian alat dan pengolahan data perbandingan Lux Meter Standar dan Lux Meter Buatan diperoleh sebagai berikut: pada jarak vertikal alat 1 meter dari lampu dihasilkan nilai selisih error rata-rata sebesar $12.571 \mathrm{~lx}$ dan persentase error rata-rata sebesar $8.77 \%$, sedangkan jarak vertikal alat 2 meter dari lampu nilai selisih error rata-rata sebesar $2.358 \mathrm{~lx}$ dan persentase error rata-rata sebesar $7.98 \%$, dan jarak vertikal alat 3 meter dari lampu nilai selisih error ratarata sebesar $0.92 \mathrm{~lx}$ dan persentase error rata-rata sebesar $5.85 \%$.
\end{abstract}

Kata Kunci: Arduino Leonardo, LCD, LDR, Cahaya. 


\section{PENDAHULUAN}

Di era globalisasi saat ini, ilmu pengetahuan dan teknologi dari waktu ke waktu mengalami perkembangan yang begitu pesat di dunia. Ilmu pengetahuan dan teknologi merupakan segala sesuatu yang berhubungan dengan teknologi, baik itu penemuan yang terbaru yang bersangkutan dengan teknologi atau perkembangan di bidang teknologi itu sendiri. Saat ini iptek telah dimanfaatkan oleh manusia. Teknologi banyak dikembangkan untuk membantu pekerjaan manusia sehingga pekerjaannya semakin lebih mudah dan efisien. Contohnya membuat dan memakai rangkaian sensor cahaya dan alat kur cahaya.

Cahaya merupakan suatu bentuk energi yang sangat penting yang dibutuhkan oleh seluruh makhluk hidup yang ada di bumi. Kehidupan di bumi dipastikan tidak berjalan sempurna tanpa adanya cahaya. Sinar putih yang biasa terlihat disebut juga cahaya tampak atau visble light terdiri dari semua komponen warna dari spektrum cahaya. Spektrum cahaya terbagi berdasarkan atas range (jarak) panjang gelombang. Menurut Gunadhi (2002), alat ukur cahaya (lux meter) adalah alat yang digunakan untuk mengukur besarnya intensitas cahaya di suatu tempat. Besarnya intensitas cahaya ini perlu diketahui karena biasanya manusia juga memerlukan penerangan yang cukup. Untuk mengetahui besarnya intensitas cahaya diperlukan sensor yang cukup peka terhadap cahaya.

Sensor adalah komponen yang dapat digunakan untuk mengkonversi suatu besaran tertentu menjadi satuan analog/digital sehingga dapat dibaca oleh suatu rangkaian elektronik. Menurut Supatmi (2011), LDR (Light Dependent Resistor) adalah salah satu jenis resistor yang nilai hambatan dipengaruhi oleh cahaya yang diterima olehnya. Nilai besar hambatan dari LDR tergantung pada besar kecilnya cahaya yang diterima oleh LDR itu sendiri.

Untuk melakukan hal tersebut perlu adanya sebuah perangkat elektronika yang dapat memenuhi kebutuhan untuk menunjang kemudahan bagi manusia. Salah satu bentuk perangkat elektronika tersebut adalah mikrokontroler. Mikrokontroler merupakan sebuah chip yang dapat diprogram sehingga dapat dimanfaatkan dalam berbagai bidang. Pendayagunaan chip ini dapat dimanfaatkan untuk pengukuran, pengontrolan, dan pengendalian sistem komunikasi data jarak jauh dan lain-lain. 
Menurut Budiyanto (2012), LCD (Liquid Crystal Display) merupakan sebuah alat untuk menampilkan suatu ukuran besaran atau angka, sehingga dapat dilihat dan diketahui melalui tampilan layar kristalnya.

\section{Banyak penelitian yang telah dilakukan untuk merancang alat ukur intensitas cahaya tampak berbasis mikrokontroler. Penelitian yang telah dilakukan Wanto (2008) "Rancang Bangun Pengukur Intensitas Cahaya Tampak Berbasis Mikrokontroler". Dengan menggunakan sensor cahaya berupa foto diode digunakan untuk mengukur intensitas cahaya dari LED (Light Emitting Diode) kemudian diubah menjadi tegangan dengan sebuah mikrokontroler ATMEGA 89S52 sebagai pengolah data. Rangkaian sensor foto diode masih menghasilkan sinyal tegangan bersifat analog. Dibutuhkan perangkat converter ADC (Analog to Digital Converter) untuk mengubah sinyal analog menjadi digital sehingga dapat diproses oleh mikrokontroler dan dikalibrasi yang selanjutnya akan ditampilkan dilayar LCD.}

Banyak pabrik menghasilkan barang yang akan di jual di pasaran, tidak akan memberi semua informasi tentang produk yang dihasilkan seperti membuat dan merancang alat ukur tekanan, suhu dan cahaya. Dalam kasus alat ukur intensitas cahaya, produsen alat ukur hanya membuat, merancang alat dan memprogram alat tersebut. Konsumen hanya memakai hasil dari buatan pabrik. Untuk merealisasikan rancangan perangkat pengukuran intensitas cahaya sederhana dalam penelitian ini, di buat suatu perangkat perancangan alat ukur intensitas cahaya berbasis Arduino Leonardo menggunakan sensor cahaya LDR. Tujuan dilakukan penelitian yaitu untuk merancang alat ukur intensitas cahaya dengan menggunakan komponen LDR sebagai sensor cahaya dan membandingkan alat ukur intensitas cahaya yang dibuat menggunakan sensor LDR dan mikrokontroler berbasis Arduino Leonardo dengan alat yang sudah baku

\section{METODE}

Waktu dan Tempat Penelitian

Penelitian ini dilakukan di Laboratorium Jurusan Fisika Fakultas FMIPA Universitas Papua (UNIPA). Penelitian ini dimulai dari bulan Oktober 2018 - Ferbruari 2020.

Tahapan Perancangan Alat Blok Diagram Rangkaian 
Perancangan blok diagram alat lux meter yang akan dibuat merupakan suatu tahapan awal dalam perancangan alat ukur intensitas cahaya berbasis Arduino Leonardo menggunakan sensor LDR, yang dapat dilihat pada Gambar 1.

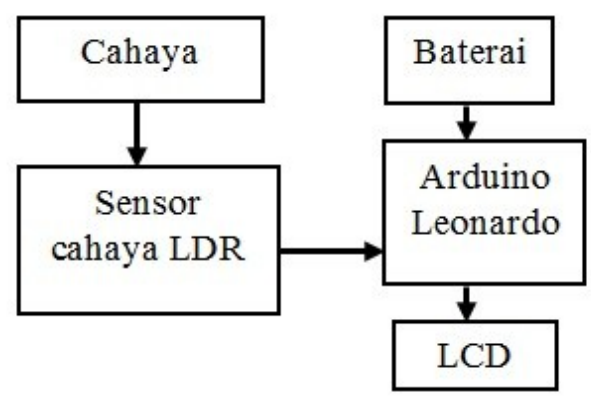

Gambar 1 Diagram Blok Rangkaian

\section{Perancangan Software}

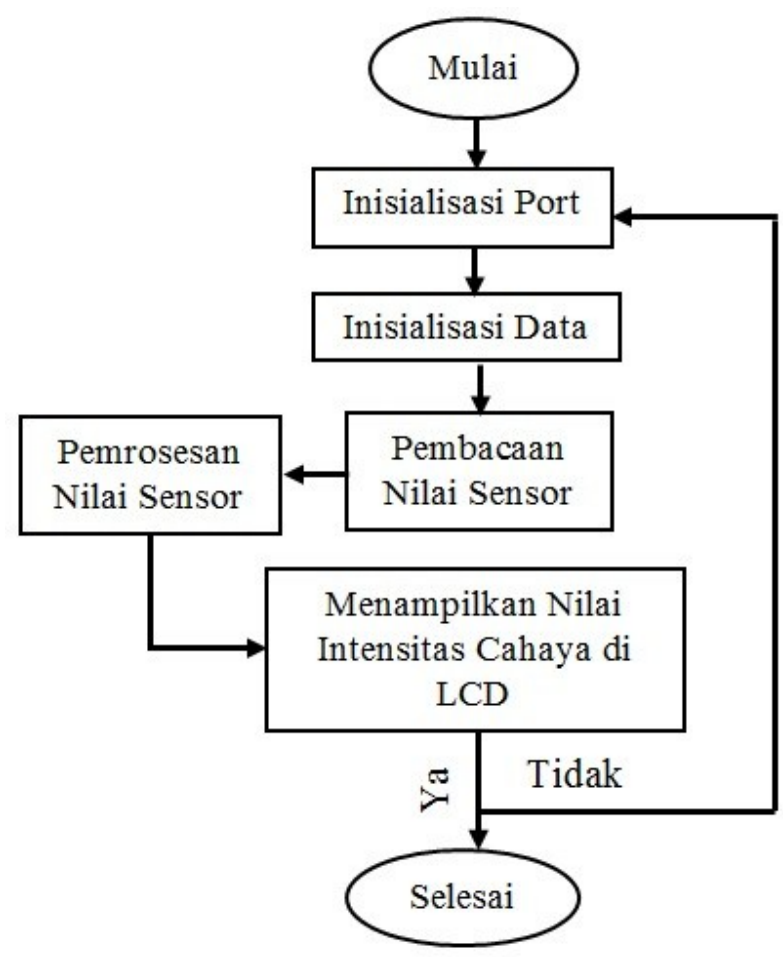

\section{Tahap Pengujian Alat}

Tabel 1 merupakan proses pengujian alat ukur intensitas cahaya dengan lampu berbasis Arduino Leonardo menggunakan sensor LDR sebagai sensor cahaya dengan metode regresi polynomial orde 2 .

Tabel.1. Pengukuran Intensitas Cahaya

\begin{tabular}{ccccc}
\hline No & $\begin{array}{c}\text { Daya } \\
\text { lampu } \\
\text { Watt }\end{array}$ & $\begin{array}{c}\text { Luxmeter } \\
\text { buatan } \\
\text { (lux) }\end{array}$ & $\begin{array}{c}\text { Luxmeter } \\
\text { standar } \\
\text { (lux) }\end{array}$ & $\begin{array}{c}\text { Regresi } \\
\text { polynomial }\end{array}$ \\
\hline 1 & 5 & $\mathrm{n} 1$ & $\mathrm{~m} 1$ & \\
2 & 8 & $\mathrm{n} 2$ & $\mathrm{~m} 2$ & \\
3 & 11 & $\mathrm{n} 3$ & $\mathrm{~m} 3$ & \\
4 & 14 & $\mathrm{n} 4$ & $\mathrm{~m} 4$ \\
5 & 18 & $\mathrm{n} 5$ & $\mathrm{~m} 5$ \\
6 & 23 & $\mathrm{n} 6$ & $\mathrm{~m} 6$ \\
7 & 27 & $\mathrm{n} 7$ & $\mathrm{~m} 7$ \\
8 & 32 & $\mathrm{n} 8$ & $\mathrm{~m} 8$ \\
9 & 35 & $\mathrm{n} 9$ & $\mathrm{~m} 9$ \\
10 & 50 & $\mathrm{n} 10$ & $\mathrm{~m} 10$ \\
\hline
\end{tabular}

. Gambar 2 Perancangan Software 


\section{Tahap Pengolahan Data}

Data yang diperoleh dalam pengukuran dengan menggunakan lux meter buatan dan lux meter standar berupa nilai analog intensitas cahaya. Untuk menentukan nilai selisih error dan persentase error (\%) yang diperoleh dari hasil pengukuran menggunakan lux meter standar dan lux meter buatan. Pada analisis data, variabel yang di gunakan adalah variabel intensitas cahaya dan nilai sensor menggunakan lux meter buatan dan lux meter standar. Metode yang digunakan dalam penelitian berupa metode regresi. Analisis data akan di plot dalam bentuk grafik yang dibuat menggunakan Microsoft Excel. Hasil yang diharapkan dalam penelitian sesuai dengan tujuan.

\section{HASIL DAN PEMBAHASAN}

Sebelum penelitian dilakukan, alat dirangkai dan diubah kode program di komputer, selanjutnya kode program ditransfer ke alat dengan menghubungkan kabel USB setelah itu dilakukan uji coba kode program apakah sudah benar atau salah sesuai dengan tujuan. Jika kode program sudah benar maka selanjutnya dilakukan uji coba menggunakan lampu dengan daya yang berbeda. Jenis lampu yang digunakan dalam penelitian adalah lampu philips CFL

\section{(Philips Essential) yang masing-masing} lampu memiliki daya 5, 8, 11, 14, 18, 23, 27, 32, 35, dan 50 Watt. Alat yang sudah dibuat dan selesai diuji coba kemudian dibandingkan dengan alat yang sudah memenuhi standar.

Data hasil uji coba kemudian diolah menggunakan MS. Excel. Hasilnya diuji coba ke persamaan logaritma, linear, eksponensial dan polynomial. Dari persamaan di atas diperoleh hasil yang paling mendekati yaitu polynomial. Berdasarkan metode regresi polynomial orde 2 dilakukan pengambilan data dengan pengukuran intensitas cahaya lampu, yang memanfaatkan aplikasi Arduino dengan menggunakan sensor LDR. Aplikasi Arduino merupakan perangkat elektronik yang digunakan untuk melakukan pengujian. Tahap selanjutnya dari pengujian dijelaskan dan ditampilkan hasil data yang diperoleh dari alat yang dibuat. Hasil data tersebut kemudian dianalisis dalam pembahasan.

\section{Pengujian Software}

Pengujian software dilakukan untuk memastikan perangkat telah bekerja dengan baik atau tidak, dimana kode program (sketch) telah dimasukkan pada mikrokontroler dengan melakukan penginputan data dari komputer. 
Kabel USB digunakan untuk menghubungkan komputer ke mikrokontroler untuk proses upload kode program (sketch).

\section{Pengujian Hardware}

Pengujian hardware dilakukan setelah semua rangkaian sudah dipastikan bekerja dengan baik, kemudian dilakukan pengukuran intensitas cahaya berbasis Arduino Leonardo menggunakan sensor LDR, seperti Gambar 3.

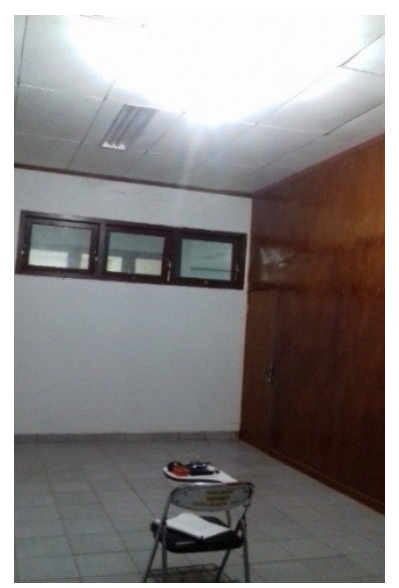

Gambar 3. Pengujian alat lux meter buatan dan standar

\section{Uji Coba Perangkat Software}

\section{a. Pengujian alat untuk pembacaan nilai sensor LDR}

Sensor LDR adalah sensor cahaya yang mengirimkan data cahaya lampu yang diukur, dimana pengujian sensor LDR terhadap cahaya lampu dengan mengubah daya lampu dengan jarak vertikal alat 2.74 dari lampu pada ruangan. Persamaan yang dilakukan dalam penelitian ini yaitu persamaan polynomial orde 2 yang dapat ditunjukkan pada Gambar 4

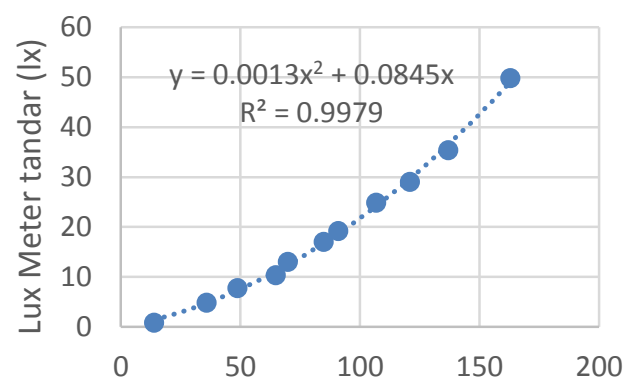

Gambar 4 Data kalibrabsieter(x) Mikretetex) standar dan buatan

\section{b. Pengukuran intensitas cahaya dengan variasi daya lampu terhadap jarak alat ukur dari lampu}

Semua alat diuji coba terlebih dahulu sebelum dilakukan pengambilan data. pengambilan data primer dilakukan dengan mengubah variasi jarak vertikal dan daya lampu yang berbeda. Dari pengujian Intensitas Cahaya berbasis Arduino Leonardo menggunakan Metode Regresi Polynomial dengan variasi daya lampu dengan jarak vertikal alat ukur dari lampu diperoleh hasil pengujian sebagai berikut 


\section{Pengujian lux meter buatan dan lux meter standar dengan jarak vertikal alat 1 meter dari lampu}

Pada jarak vertikal alat 1 meter dari lampu nilai selisih error semakin besar karena arus cahaya, intensitas cahaya dan kuat penerangan tidak menyebar merata atau kurang stabil. Nilai selisih error rata-rata sebesar 12.571 lx dan persentase error sebesar 8.77 \%. Daya lampu berbanding lurus dengan lux meter, dimana semakin besar daya lampu maka semakin besar nilai lux yang dilihat pada Gambar 5

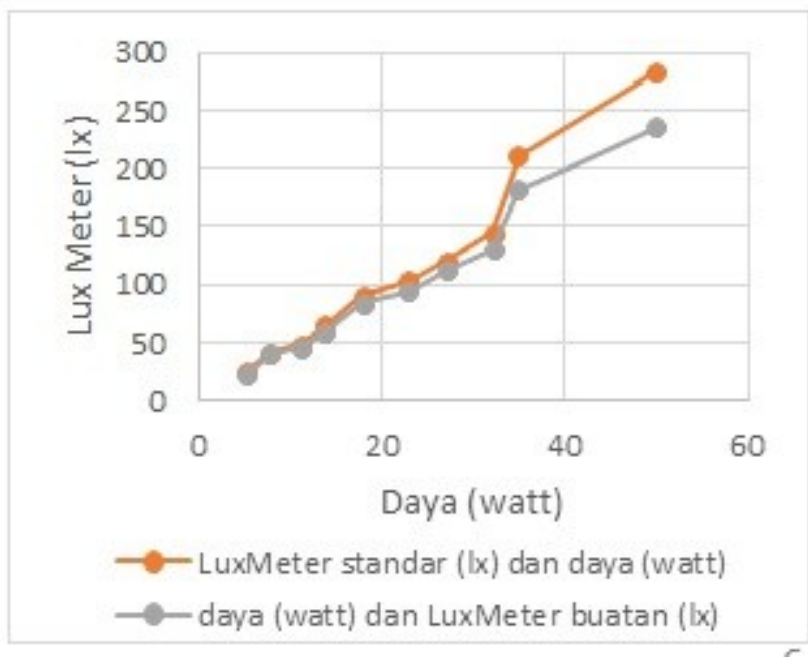

Gambar 5. Data hasil pengujian sensor LDR terhadap lux meter dengan jarak vertikal 1 meter dari lampu

2. Pengujian lux meter buatan dan lux meter standar dengan jarak vertikal alat 2 meter dari lampu
Pada jarak vertikal alat 2 meter dari lampu nilai selisih error semakin menurun, dimana jika jarak vertikal alat semakin dekat dari lampu maka nilai selisih error semakin besar begitu juga sebaliknya, karena arus cahaya, intensitas cahaya dan kuat penerangan menyebar merata atau stabil. Nilai selisih error rata-rata sebesar $2.358 \quad \mathrm{~lx}$ dan persentase error $7.98 \%$, dimana daya lampu berbanding lurus dengan lux meter, yaitu semakin besar daya lampu maka semakin besar nilai lux. Data hasil pengujian sensor LDR terhdapat lux meter ditunjukkan pada Gambar 6

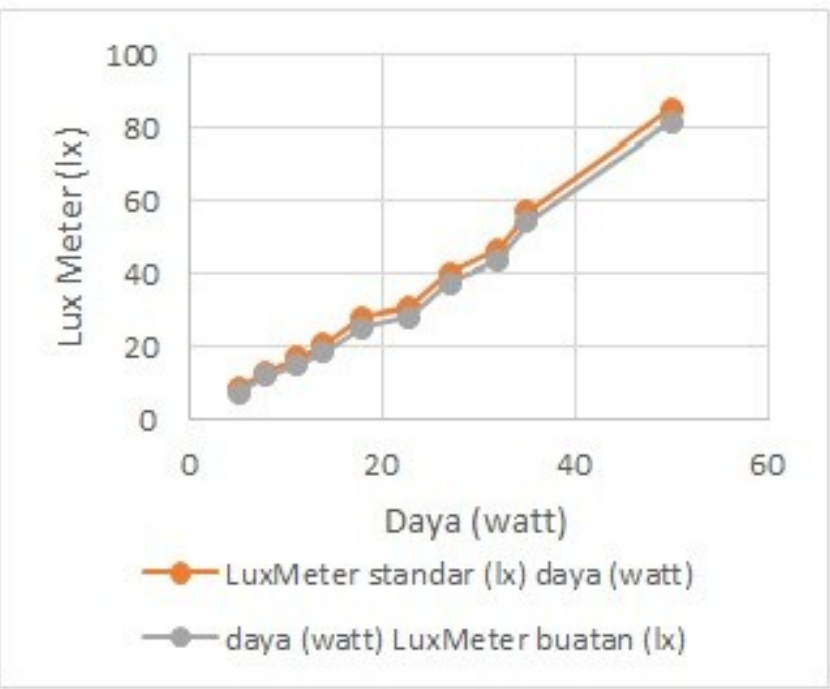

Gambar 6. Data hasil pengujian sensor LDR terhadap lux meter dengan jarak verikal alat 2 meter dari lampu 


\section{Pengujian lux meter buatan dan lux meter standar dengan jarak vertikal alat 3 meter dari lampu}

Pada jarak vertikal alat 3 meter dari lampu nilai selisih error menurun dimana jika jarak vertikal alat semakin dekat dari lampu maka nilai selisih error semakin besar begitu juga sebaliknya, karena arus cahaya, intensitas cahaya dan kuat penerangan menyebar secara merata atau stabil. Selisih nilai error rata-rata sebesar $0.921 \mathrm{x}$ dan nilai persentase error sebesar $5.85 \%$. Daya lampu berbanding lurus dengan lux meter, karena semakin besar daya lampu maka semakin besar nilai lux. Data hasil pengujian sensor LDR terhadap lux meter ditunjukkan pada Gambar 7semakin besar daya lampu maka semakin besar nilai lux. Data hasil pengujian sensor LDR terhadap lux meter ditunjukkan pada Gambar 7.

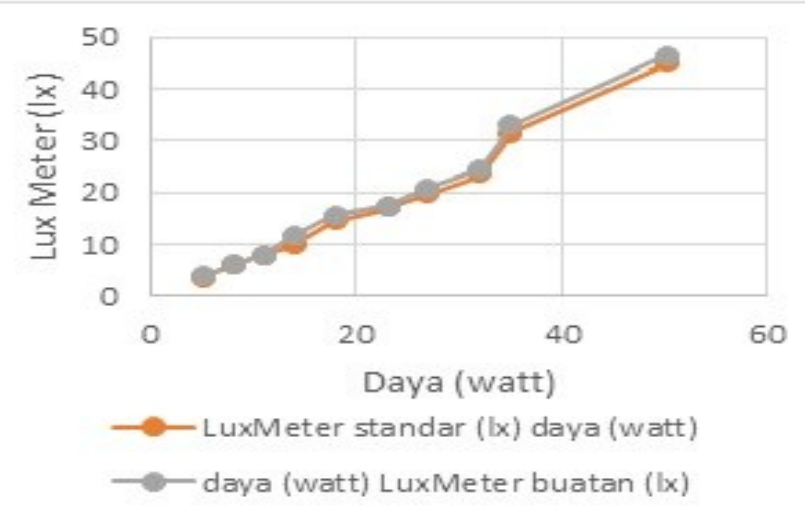

Gambar 7. Data hasil pengujian sensor LDR terhadap lux meter dengan jarak vertikal alat 3 meter dari lampu

\section{Perhitungan Tingkat Pencahayaan}

Hasil perhitungan tingkat pencahayaan ruangan secara teoritk dengan jarak vertikal alat 1, 2 dan 3 meter dari lampu yang diperoleh dari rumus persamaan (2.1) dapat dilihat pada Tabel 2, 3 dan 4.

Tabel 2 Perhitungan tingkat pencahayaan jarak vertikal alat 1 meter dari lampu

\begin{tabular}{cccccc}
\hline $\begin{array}{c}\text { Daya } \\
\text { (watt) }\end{array}$ & Kp & Kd & $\begin{array}{c}\text { A } \\
\left(\mathrm{m}^{2}\right)\end{array}$ & F1 (lm) & $\begin{array}{c}\text { Erata- } \\
\text { rata (lx) }\end{array}$ \\
\hline 5 & 0.59 & 0.8 & 27.09 & 235 & 4.1 \\
8 & 0.59 & 0.8 & 27.09 & 400 & 7 \\
11 & 0.59 & 0.8 & 27.09 & 594 & 10.34 \\
14 & 0.59 & 0.8 & 27.09 & 680 & 11.91 \\
18 & 0.59 & 0.8 & 27.09 & 920 & 16.02 \\
23 & 0.59 & 0.8 & 27.09 & 1170 & 20.39 \\
27 & 0.59 & 0.8 & 27.09 & 1500 & 26.13 \\
32 & 0.59 & 0.8 & 27.09 & 1800 & 31.37 \\
35 & 0.59 & 0.8 & 27.09 & 2200 & 38.33 \\
50 & 0.59 & 0.8 & 27.09 & 3100 & 54.01 \\
\hline
\end{tabular}


Tabel 3. Perhitungan tingkat pencahayaan jarak vertikal alat 2 meter dari lampu

\begin{tabular}{cccccc}
\hline $\begin{array}{c}\text { Daya } \\
\text { (watt) }\end{array}$ & Kp & Kd & $\begin{array}{c}\text { A } \\
\left(\mathrm{m}^{2}\right)\end{array}$ & F1 (lm) & $\begin{array}{c}\text { Erata- } \\
\text { rata (lx) }\end{array}$ \\
\hline 5 & 0.39 & 0.8 & 27.09 & 235 & 2.70 \\
8 & 0.39 & 0.8 & 27.09 & 400 & 4.60 \\
11 & 0.39 & 0.8 & 27.09 & 594 & 6.84 \\
14 & 0.39 & 0.8 & 27.09 & 680 & 7.83 \\
18 & 0.39 & 0.8 & 27.09 & 920 & 10.60 \\
23 & 0.39 & 0.8 & 27.09 & 1170 & 13.48 \\
27 & 0.39 & 0.8 & 27.09 & 1500 & 17.28 \\
32 & 0.39 & 0.8 & 27.09 & 1800 & 20.73 \\
35 & 0.39 & 0.8 & 27.09 & 2200 & 25.33 \\
50 & 0.39 & 0.8 & 27.09 & 3100 & 35.70 \\
\hline
\end{tabular}

Tabel 4. Perhitungan tingkat pencahayaan jarak vertikal alat 3 meter dari lampu

\begin{tabular}{cccccc}
\hline $\begin{array}{c}\text { Daya } \\
\text { (watt) }\end{array}$ & $\mathrm{Kp}$ & $\mathrm{Kd}$ & $\begin{array}{c}\mathrm{A} \\
\left(\mathrm{m}^{2}\right)\end{array}$ & $\begin{array}{c}\mathrm{F} 1 \\
(\mathrm{~lm})\end{array}$ & $\begin{array}{c}\text { Erata- } \\
\text { rata }(\mathrm{lx})\end{array}$ \\
\hline 5 & 0.48 & 0.8 & 27.09 & 235 & 3.33 \\
8 & 0.48 & 0.8 & 27.09 & 400 & 5.7 \\
11 & 0.48 & 0.8 & 27.09 & 594 & 8.41 \\
14 & 0.48 & 0.8 & 27.09 & 680 & 9.7 \\
18 & 0.48 & 0.8 & 27.09 & 920 & 13.04 \\
23 & 0.48 & 0.8 & 27.09 & 1170 & 16.59 \\
27 & 0.48 & 0.8 & 27.09 & 1500 & 21.27 \\
32 & 0.48 & 0.8 & 27.09 & 1800 & 25.51 \\
35 & 0.48 & 0.8 & 27.09 & 2200 & 31.19 \\
50 & 0.48 & 0.8 & 27.09 & 3100 & 43.94 \\
\hline
\end{tabular}

Pada hasil perhitungan tingkat pencahayaan ruangan secara teoritik dibandingkan dengan hasil pencahayaan pengukuran dengan jarak vertikal alat 1, 2 dan 3 meter dari lampu.

Perbandingan antara lux meter standar, lux meter buatan dan lux teoritik yaitu semakin besar daya lampu yang digunakan maka nilai lux semakin naik. Nilai lux meter buatan jauh lebih mendekati lux meter standar dibandingkan dengan lux teoritik yang nilainya lebih jauh. Hubungan antara lux meter buatan, lux meter standar dan lux teoritik dapat digambarkan dalam bentuk grafik yang ditunjukkan pada Gambar 8

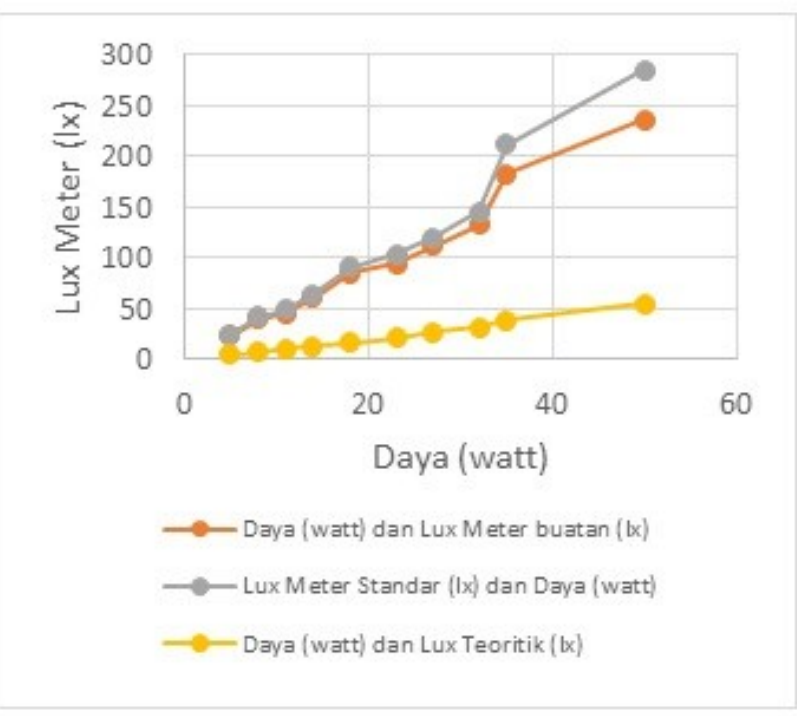

Gambar 8. Hubungan daya lampu dan lux meter buatan, lux meter standar dan lux teoritik vertikal alat 1 meter dari lampu 
Perbandingan antara lux meter standar, lux meter buatan dan lux teoritik yaitu semakin besar daya lampu yang digunakan maka nilai lux semakin besar. Nilai lux meter buatan lebih mendekati lux meter standar jika dibandingkan dengan lux teoritik. Hubungan antara lux meter buatan, lux meter standar dan lux teoritik dapat digambarkan dalam bentuk grafik yang ditunjukkan pada Gambar 9

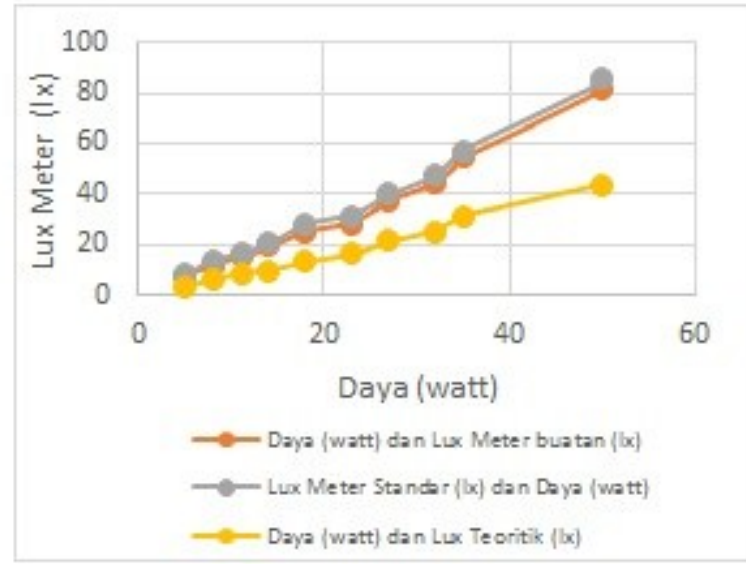

Gambar 9. Hubungan daya lampu dan lux meter buatan, lux meter standar dan lux teoritik, jarak vertikal alat 2 meter dari lampu

Perbandingan antara lux meter standar, lux meter buatan dan lux teoritik yaitu semakin besar daya lampu yang digunakan maka nilai lux makin naik. Nilai lux meter buatan lebih mendekati lux meter standar dan nilai lux teoritik tidak terlalu jauh dari nilai lux meter standar. Hubungan antara lux meter buatan, lux meter standar dan lux teoritik dapat digambarkan dalam bentuk grafik. Ditunjukkan pada Gambar 10.

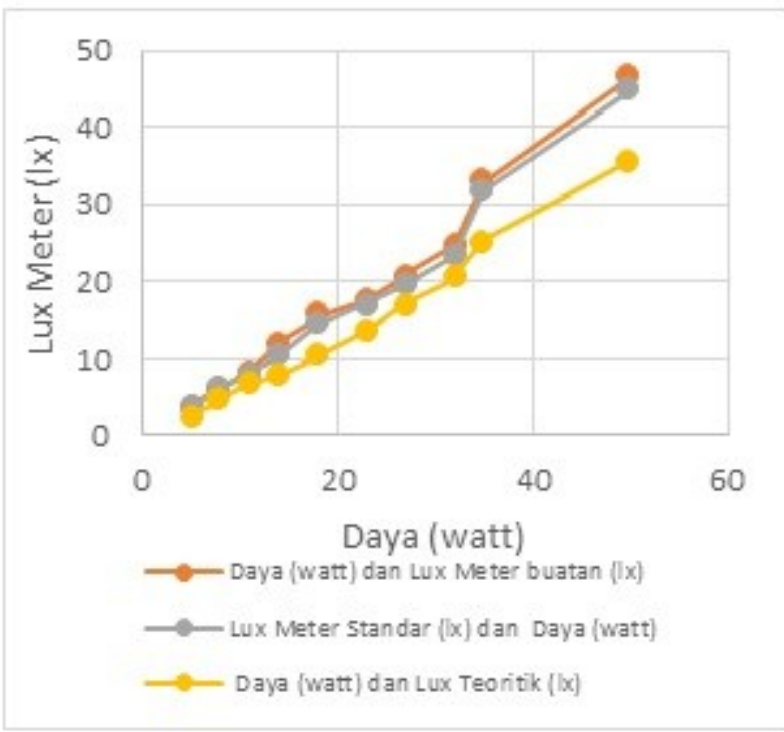

Gambar 10. Hubungan daya lampu dan lux meter buatan, lux meter standar dan lux teoritik, jarak vertikal alat 3 meter dari lampu

\section{KESIMPULAN}

1. Alat ukur intensitas cahaya dengan menggunakan sensor LDR sebagai sensor cahaya dapat digunakan mengukur intensitas cahaya di dalam ruangan.

2. Pada jarak vertikal alat 1 meter dari lampu menghasilkan nilai selisih error rata-rata sebesar $12.571 \mathrm{~lx}$ dan persentase error rata-rata sebesar $8.77 \%$, sedangkan jarak vertikal alat 2 meter dari lampu nilai selisih error rata-rata sebesar 2.358 lx dan persentase error raata-rata sebesar $7.98 \%$, dan jarak vertikal alat 3 meter dari lampu nilai selisih error rata-rata 
sebesar 0.92 lx dan persentase error raata-

3. Hasil perbandingan perhitungan pengukuran intensitas cahaya menggunakan lux meter buatan, lux meter standar dan lux teoritik sebagai berikut: pada jarak vertikal alat 1 meter dari lampu diperoleh nilai intensitas cahaya pada lux meter buatan sebesar 22.5 lx sampai 235.09 lx, sedangkan pada lux meter standar diperoleh nilai lux sebesar 24.5 1x sampai 284 lx dan lux teoritik diperoleh nilai sebesar 4.1 lx sampai 54.01 1x mengalami peningkatan intensitas cahaya. Pada jarak vertikal alat 2 meter dari lampu diperoleh nilai intensitas cahaya pada lux meter buatan sebesar $7.48 \quad 1 \mathrm{x}$ sampai $81.51 \quad \mathrm{~lx}$, sedangkan pada lux meter standar diperoleh nilai sebesar sebesar 8.35 1x sampai 85.3 lx dan lux teoritik diperoleh nilai sebesar 3.33 lx sampai 43.94 lx mengalami peningkatan intensitas cahaya. Pada jarak vertikal alat 3 meter dari lampu diperoleh nilai intensitas cahaya pada lux meter buatan sebesar 4.04 lx sampai 46.8 lx , sedangkan pada rata sebesar $\quad 5.85 \quad \%$. lux meter standar diperoleh nilai lux sebesar 3.69 lx sampai 45.1 lx dan lux teoritik diperoleh nilai sebesar $2.70 \mathrm{~lx}$ sampai 35.70 lx mengalami peningkatan intensitas cahaya.

\section{DAFTAR PUSTAKA}

Budiyanto, Setiyo. 2012. Sistem Logger Suhu dengan Menggunakan Komunikasi Gelombang Radio. Jurnal Teknologi Elektro, Vol.3 No 1.

Gunadhi, Albert. (2002). Perancangan dan Implementasi Alat Ukur Cahaya Sederhana. Universitas Widya Mandala Surabaya.

Supatmi, Sri. 2011. "Pengaruh Sensor LDR Terhadap Pengontrolan Lampu." Jurnal, Jurusan Teknik Komputer Universitas Indonesia.

Wanto 2008. Rancangan Bangunan Pengukur Intensitas Cahaya Tampak Berbasis Mikrokontroler. Skripsi. Universitas Indonesia. 


\section{Lampiran:}

Skema rangkaian Alat Ukur Intensitas Cahaya Berbasis Arduino Leonardo Menggunakan

\section{Sensor LDR}

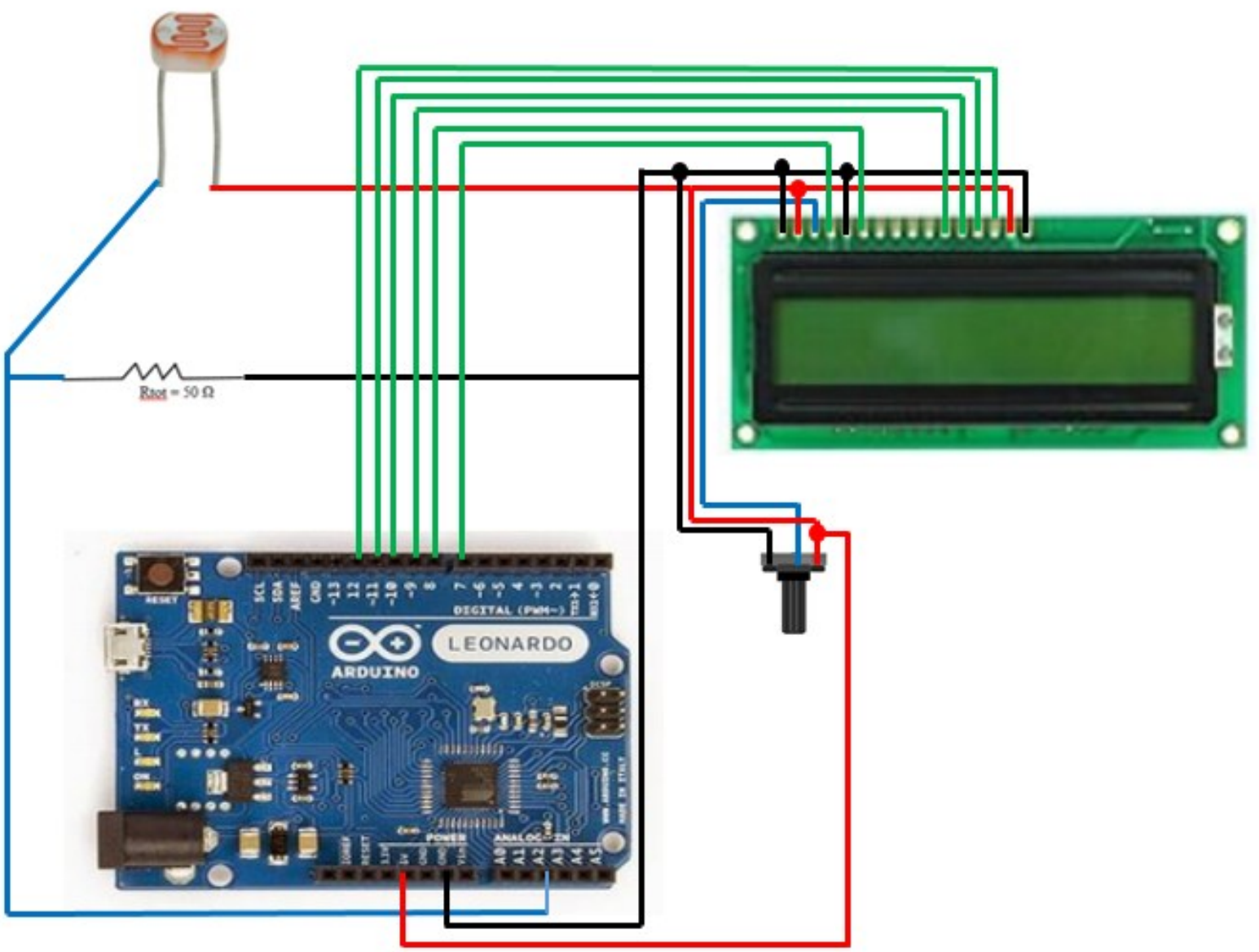

Source code:

// initialize the library with the numbers of the interface pins LiquidCrystal Icd $(7,8,9,10,11,12)$;

int sensorPin $=A 2$;

int sensorValue $=\mathrm{A} 2$;

void setup() \{

// set up the LCD's number of columns and rows:

Icd.begin(16, 2);

Serial.begin(9600);

\}

void loop() \{ 
int i;

sensorValue=analogRead(sensorPin);//membaca nilai dari sensor:

Serial.print("Int Cahaya:");

Serial.printIn(sensorValue); //menulis nilai sensor di layar monitor

float y;

$\mathrm{y}=(0.0013 *($ sensorValue $) *($ sensorValue $))+0.0845 *($ sensorValue $)$;

Icd.setCursor $(0,0)$;

// print the number of seconds since reset:

Icd.print("sensor:"); //nilai pembacaan sensor

Icd.print(sensorValue);

Icd.setCursor(0, 1);

Icd.print("Int Cahaya:");//nilai regresi

Icd.print(y);

$\operatorname{delay}(3000)$;

Icd.clear();

\} 